\title{
Model for Forecasting the Development of Small and Medium-Sized Enterprises in the Region
}

\author{
Erik Avanesian*
}

\author{
Ural State University of Economics, Ekaterinburg, Russia \\ ${ }^{*}$ Corresponding author.Email: avanesyan2013@mail.ua
}

\begin{abstract}
The article simulates indicators of the level of development of the small and medium-sized enterprises using the Sverdlovsk region as an example. It is shown that the development of small and medium-sized enterprises is a key factor in the economic development of the region, which determines the importance of state policy aimed at its development. An analysis of the growth factors of this sector of the economy shows that there are no unified indicators applicable to all regions of the country. To develop strategies for the development of SMEs, it is necessary to take into account the specifics of regional development by building economic and mathematical models applicable to individual constituent entities of the Russian Federation. The authors attempted to develop a model for predicting the level of development of small and medium-sized enterprises as in the example of the Sverdlovsk region, based on methods of economic and mathematical modeling using logarithmic and linear models. It is shown that the key factors in the development of the region's small and medium-sized enterprises sector are the costs of research and development, the costs of developing information and communication technologies, as well as the share of the urban population in the region. The above factors have a positive effect on the development of small and medium-sized enterprises, both in terms of growth in the sector's turnover and in terms of growth in the number of SMEs. The forecasting model shows that the increased R\&D and ICT costs, as well as the urbanization policy, allow achieving the targets set in the Strategy for the Development of Small and Medium-Sized Enterprises in the region.
\end{abstract}

Keywords: small enterprise, medium-sized enterprise, regional development, SMEs, regional factors, economic factors

\section{INTRODUCTION}

Small and medium-sized enterprises (SMEs) are small-scale economic activities where businesses are not formally affiliated with other firms. The criteria for classifying economic entities as small and medium-sized enterprises are established by Federal Law No. 209-FL which provides threshold values for revenue, the number of employees, as well as the share in the company capital [[11]].

The role of small and medium-sized enterprises is widely discussed in the scientific community, since small and medium-sized enterprises are innovatively active and are able to occupy the market niches in which large enterprises turn out to be less effective due to the lack of flexibility of their organizational structure. Small and medium-sized enterprises create healthy competition in the markets of goods and services, as opposed to the trends for enlargement of production and monopolization of markets. They also create additional jobs, which is especially important in the context of digitalization of the economy, where human labor is gradually being algorithmized and replaced by the digital economy products. Thus, in addition to the economic role, small and medium-sized enterprises also perform social functions, which determines the relevance and necessity of studying the factors of its development not only in terms of the economies of individual countries, but at the regional level as well.

In the economies of developed countries, the share of the small and medium-sized enterprises sector accounts for approximately half of the GDP. In Russia, its share is estimated as $20 \%$ [[5]]. The national project "Small and Medium Enterprises and Support of Individual Entrepreneurial Initiatives" sets a priority task to increase the share of the SME sector to $32.2 \%$ by 2024 [[4]]. However, the COVID-19 pandemic and introducing restrictive measures had a negative impact on the 
development of the entrepreneurial initiative in the country: in 2020, every fifth small business closed down [[2]].

The objectives of the national project can be achieved through focused effort to develop and support entrepreneurship in the regions. The development of SMEs should be a priority task of the policy, since this sector of the economy makes it possible to smooth out disparities in the socio-economic development of the regions through more efficient use of available resources. It contributes to the diversification of the economy, creates jobs, ensures an increase in people's incomes, fills the market niches, in which large enterprises are economically ineffective, develops intellectual potential, introduces innovations, etc. [[3]]. The importance of developing the small and medium-sized enterprise is discussed in the works of Russian and foreign authors. So, N.Z. Solodilova, R.I. Malikov, K.E. Grishin point out that the modernization of the Russian economy and transition to innovative development are impossible without creating favorable conditions for the development of entrepreneurship. Small and mediumsized enterprises act as a driver of economic development, but at present, the development of the entrepreneurial initiative sector is unsatisfactory. The authors think that the problem of stimulating entrepreneurial initiative in the Russian economy is understudied [6].

Kelly D. Edmiston in his scientific work justifies the importance of developing the SME sector, since small and medium-sized enterprises perform important social functions, namely: creating additional jobs, which is especially important in the context of the digitalization of the economy and computerization, which means staff reductions at large enterprises. This author also shows that in the developed economies, more and more attention is paid to the SME sector, since this strategy has a positive effect on the growth rate of the economy [12]

Small and medium-sized enterprises (SMEs) are at the core of economic development, as they are more innovative than large companies are. The innovative activity of small firms is a source of progress and a growth factor for the welfare of modern economies.[13]. Thus, the development of the small and medium-sized enterprises sector makes it possible to solve the problems associated with the slowdown in the development of the Russian economy at both the regional and national levels.

Building a model for the development of the small and medium-sized enterprises sector is currently an urgent task, since, on the one hand, mathematical modeling makes it possible to substantiate the expediency of spending budget funds and highlight the overall economic effect of the implemented stimulative policy, and on the other hand, it will help to achieve the goal of the national program to increase the share of the SME sector in the Russian economy.

Relatively little attention is paid to the issues of modeling and forecasting the development of small and medium-sized enterprises in the scientific community. Consider the results and conclusions obtained by modern authors in their works devoted to this topic.

The research paper of G.V. Tikhonov, A.I. Tikhonov examines the effectiveness of measures of state support for the innovative activity of small enterprises. The authors also prove the validity of mathematical modeling tools as the basis for making decisions on budget expenditures [8]. In this case, it should be noted that in accordance with the main provisions of the Strategy for the Development of Small and Medium-Sized Businesses in the Sverdlovsk Region, joint financing of R\&D costs is provided for, which proves the importance of analyzing the statistical relationship between the $R \& D$ costs and the SME development indicators. [7].

In the scientific article by S.V. Doroshenko, A.G. Shelomentsev the authors present the results of the analysis on how the demographic factor influences the development of entrepreneurship in the regions of the Russian Federation using statistical methods of assessment. These researchers prove a statistically significant relationship between the number of young people (population aged 20 to 34) and the number of SMEs in the area. The work shows that the size of the young population is a factor reflecting migration sentiments, which has an effect on the development of entrepreneurial initiative. According to the study, the support provided for entrepreneurial initiative reduces migration sentiments among the young population, and the young people's staying in the regions contributes to the development of the small and medium-sized enterprises sector. The dependent variable in the economic model is the number of SMEs, and the explanatory variable is the number of young people. The data were taken for Russia as a whole [1]. In our opinion, the conclusion obtained by the authors is very important for forecasting the level of development of entrepreneurship, since in most regions of the country there is a migration outflow of the young population to the regions with higher standards of living and favorable socio-economic conditions. According to the logic of the authors of the article, the population migration in the long and short term negatively affects the enterprise development and the main economic indicators of the region.

In the work of N.A. Knysh, E.V. Verlup the authors show the importance of considering the specifics of the region when outlining the state support measures the example of Omsk region. The authors show that the regions have different budgetary, resource and demographic potential, due to what it is necessary to assess the indicators of entrepreneurial initiative in the 
context of a particular region. State programs of small and medium-sized enterprises support to improve their efficiency and effectiveness should take into account the regional capacity. The work emphasizes the importance of mathematical modeling in preparing and implementing regional development programs, since this fully corresponds to the approach prevailing in the developed economies [3].

\section{MATERIALS AND METHODS}

The purpose of this study is to develop a model for forecasting the level of development of small and medium-sized enterprises in the region using the example of the Sverdlovsk region. The materials for the study are data from official statistics on the development of small and medium-sized enterprises in the region under study. Research methods are as follows: bibliographic research, economic and mathematical modeling, forecasting, method of development scenarios, analysis and synthesis. To construct predictive values for the turnover of the small and medium-sized business sector for 2025 and 2035, statistical data are taken for the period from 2010 to 2018 , posted on the websites of the Federal State Statistics Service (Rosstat) and on the website of the Federal State Statistics Service for the Sverdlovsk and Kurgan regions.

To build the predictive values of the turnover in the SME sector, a logarithmic model is used:

$$
\operatorname{Ln}(\mathrm{Y})=\mathrm{a} * \operatorname{Ln}(\mathrm{X})+\mathrm{Ui},
$$

where $\mathrm{Y} 1$ is the turnover of the SME sector, billions per year;

$\mathrm{X} 1$ is the cost of R\&D and ICT development, billions per year.

Due to the identified specification, the interpretation of the coefficients of the model (1) requires clarification. The coefficient "a" in this model means the coefficient of factor elasticity, reflecting the strength of the change in the explained variable depending on the change in the explanatory variable in percent:

$$
\frac{\% \text { change } Y}{\% \text { change } \mathrm{X}}=\frac{\Delta Y / Y}{\Delta X / X}=\frac{\partial \operatorname{Ln}(Y)}{\partial \operatorname{Ln}(x)}=a,
$$

where the ratio of the percentage change in the variable $\mathrm{Y} 1$ to the percentage change in $\mathrm{X} 1$ is the mathematical meaning of the elasticity coefficient, and the parameter "a" is the estimated element of the regressive equation.

Based on equation (2), the economic meaning of the coefficient " $\mathrm{a}$ " is that when the variable $\mathrm{X}$ changes by $1 \%$, the value of the variable $\mathrm{Y}$ will change by $\mathrm{a} \%$.

To build a second model describing the dynamics of changes in the number of small and medium-sized enterprises, a standard linear model of the form is used:

$$
\mathrm{Y}=\mathrm{a}+\mathrm{b} * \mathrm{X}+\mathrm{Ui},
$$

where $\mathrm{Y} 2$ is the number of SMEs, thousand units;

$\mathrm{X} 2$ is the share of the urban population, $\%$.

The interpretation of the model's results is intuitive: an increase in the independent variable (X2) by one leads to an increase in the explained variable (Y2) by b units.

The initial data used to build models (1) and (3) are presented in Table 1.

\section{RESULTS AND DISCUSSION}

In the process of studying the factors influencing the development of the small and medium-sized enterprises sector the example of the Sverdlovsk region, the conclusions presented in the work of S.V. Doroshenko, A.G. Shelomentsev were revised. In their work they investigated the relationship between entrepreneurship and the number of young people. However, in the process of statistical analysis, this hypothesis was not accepted for the region under consideration. The quantity factor of the population aged 20 to 34 does not have a statistically significant effect on the indicators of SME development. Moreover, the negative dynamics of population growth against the growth indicators of small and medium-sized enterprises leads to the fact that there is an inverse relationship between the indicators, which can lead to distortions or false interpretation of the results. Thus, it is advisable to agree with the conclusions of N.A. Knysh and E.V. Verlup stating that when assessing the parameters of small and medium-sized enterprises

Table 1. Initial data on the parameters of SME development in the Sverdlovsk region

\begin{tabular}{|c|c|c|c|c|}
\hline Year & $\begin{array}{c}\text { Y1: SME turnover, billion } \\
\text { rubles }\end{array}$ & $\begin{array}{c}\text { X1: R\&D and ICT expenditures, } \\
\text { billion rubles. }\end{array}$ & $\begin{array}{c}\text { Y2: Number of SMEs, } \\
\text { thousand units }\end{array}$ & $\begin{array}{c}\text { X2: Share of urban } \\
\text { population, } \%\end{array}$ \\
\hline 2010 & 887.23 & 31.57 & 146.78 & 83.7 \\
\hline 2011 & 964.14 & 37.85 & 129.18 & 83.9 \\
\hline 2012 & 1035.7 & 40.73 & 153.14 & 84.0 \\
\hline 2013 & 1132.08 & 48.15 & 171.82 & 84.1 \\
\hline 2014 & 1076.42 & 56.60 & 190.84 & 84.2 \\
\hline 2015 & 1197.68 & 58.15 & 176.38 & 84.3 \\
\hline 2016 & 1418.88 & 52.82 & 200.51 & 84.5 \\
\hline 2017 & 14297.72 & 61.23 & 205.05 & 84.6 \\
\hline 2018 & 14996.21 & 60.78 & 202.65 & 8 \\
\hline
\end{tabular}


development, it is necessary to take into account the individual characteristics of the regions.

Thus, based on the correlation analysis, the following data are used to assess the predicted values of the turnover in the small and medium-sized enterprises sector:

1. The value of the annual turnover of small and medium-sized enterprises, including microenterprises, billion rubles. (Y1).

2. Amount of R\&D costs and costs of ICT development, billion rubles. (X1).

Since the relationship between the indicators is nonlinear, the following specification of the model (1) was chosen, which makes it possible to bring the relationship between the explained and explanatory variables to a linear form. As a result of mathematical modeling, the following dependence was received:

$$
\operatorname{Ln}(\mathrm{Y} 1)=1.95 * \operatorname{Ln}(\mathrm{X} 1)+\mathrm{Ui},
$$

The R-squared for the model under consideration is 0.98 . The model is significant and has a high explanatory power, explaining $98 \%$ of the change in the dependent variable. The economic meaning of the coefficient $\mathrm{a}=$ 1.95 is that with an increase in the variable $\mathrm{X}$ by $1 \%$, the variable $\mathrm{Y}$ will increase by $1.95 \%$.

To make the forecast, the average annual data on the growth of $\mathrm{R} \& \mathrm{D}$ costs and costs of information and communication technologies were used. It was found that the average annual growth rates for the period under review from 2010 to 2018 amounted to $1 \%$ per year. These data were taken as the basis when considering the forecast for the development of the small and mediumsized enterprises sector in the Sverdlovsk region. If during 2017-2025 the average annual growth rate of R\&D and ICT costs will remain at the current level, their overall growth will average $7 \%$. The optimistic scenario assumes that costs will be increased by 2 times, and the pessimistic scenario is they will be reduced by 2 times due to the influence of unfavorable external factors. In a similar way, calculations were made of the total increase in R\&D and ICT costs for the period up to 2035. The calculation results are presented in table. 2 .

The second economic and mathematical model aims to explain the dynamics of changes in the number of small business entities in the region. The statistical analysis revealed that the share of the urban population directly affects the dynamics of the number of SMEs.

Economic and mathematical modeling makes it possible to obtain the following relationship between the number of small and medium-sized enterprises and the share of the urban population:

$$
\mathrm{Y} 2=-6198+75.65 \mathrm{X} 2+\mathrm{Ui},
$$

The R-squared for this model is 0.85 . This means that the presented model explains $85 \%$ of the changes in the dependent variable, and $15 \%$ of the changes are due to other factors. The model is significant; the constant and variable X2 are significant at the 5\% significance level. Based on the model obtained, the conclusion can be made that an increase in the share of the urban population leads to an increase in the number of SMEs by 75.65 thousand units.

This pattern shows that the demand for the products of small and medium-sized enterprises is mainly from the urban population; therefore, an increase in the share of the urban population has a beneficial effect on the development of the sector. Let us consider the forecast for the development of the sector in terms of the number of SMEs for the future until 2025 and until 2035 with different variations of changing in the share of the urban population (Table 3).

The presented data show that urbanization has a positive effect on the development of small and medium-

Table 2. Forecast of the size of turnover of the SME sector for 2025 and 2035

\begin{tabular}{|c|c|c|c|c|c|c|}
\hline \multirow{2}{*}{ Scenario } & \multicolumn{3}{|c|}{ Forecast for 2025 } & \multicolumn{3}{c|}{ Forecast for 2035 } \\
\cline { 2 - 7 } & $\begin{array}{c}\text { R\&D cost } \\
\text { growth, } \%\end{array}$ & $\begin{array}{c}\text { Growth in SME } \\
\text { sector turnover, } \%\end{array}$ & $\begin{array}{c}\text { SME sector } \\
\text { turnover, billion } \\
\text { rubles }\end{array}$ & $\begin{array}{c}\text { R\&D cost } \\
\text { growth, } \%\end{array}$ & $\begin{array}{c}\text { Growth in SME } \\
\text { sector turnover,\% }\end{array}$ & $\begin{array}{c}\text { SME sector } \\
\text { turnover, billion } \\
\text { rubles }\end{array}$ \\
\hline Optimistic & fourteen $\%$ & $27.30 \%$ & 19090.18 & $34 \%$ & $66.30 \%$ & 24938.70 \\
\hline Realistic & $7 \%$ & $13.65 \%$ & 17043.19 & $17 \%$ & $33.15 \%$ & 19967.46 \\
\hline Pessimistic & $4 \%$ & $6.83 \%$ & 16019.70 & eight $\%$ & $15.60 \%$ & 17335.62 \\
\hline
\end{tabular}

Table 3. Forecast for the number of SMEs for 2025 and 2035

\begin{tabular}{|l|c|c|c|c|}
\hline \multirow{2}{*}{ Scenario } & \multicolumn{2}{|c|}{ Forecast for 2025 } & \multicolumn{2}{|c|}{ Forecast for 2035 } \\
\cline { 2 - 5 } & $\begin{array}{c}\text { Share of urban } \\
\text { population }\end{array}$ & $\begin{array}{c}\text { Number of SMEs, thousand } \\
\text { units }\end{array}$ & $\begin{array}{c}\text { Share of urban } \\
\text { population }\end{array}$ & $\begin{array}{c}\text { Number of SMEs, thousand } \\
\text { units }\end{array}$ \\
\hline Optimistic & $90 \%$ & 206.59 & $95 \%$ & 210.37 \\
\hline Realistic & $85 \%$ & 202.80 & $90 \%$ & 206.59 \\
\hline Pessimistic & $80 \%$ & 199.02 & $85 \%$ & 202.80 \\
\hline
\end{tabular}

Source: compiled from $[9,10]$ 
sized enterprises. If the share of the urban population is $90 \%$ by 2025 , then the number of SMEs will be 206.59 thousand units. By 2035, with an increase in the share of the urban population to $95 \%$, the number of SMEs will increase to 210.37 thousand units.

\section{CONCLUSIONS}

Regional forecasting is a key element in regulating the socio-economic development of the economic system in the region. Forecasting solves the problem of finding growth drivers for target indicators of regional development. This paper forecasts the development of the small and medium-sized enterprises in terms of the turnover size and the number of SMEs.

The study shows that in the conditions of uneven development of regions, it is impossible to draw up unified econometric models for modeling and forecasting target indicators. This finding was confirmed based on testing the hypothesis of S.V. Doroshenko, A.G. Shelomentsev. The above hypothesis was proved at the level of the Russian economy, but not proved at the level of regional economic development. Thus, under current conditions it is unacceptable to apply the models developed based on statistical data for Russia as a whole to individual regions of the country.

The development of each constituent entity of the Russian Federation is unique and depends on many factors that are non-statistically identifiable. For example, the Sverdlovsk region is characterized by natural population decline. Over the period from 2010 to 2018 , the number of the working-age population decreased by 288.8 thousand people. Thus, evaluating the dynamics of the development of the SME sector depending on the demographic factor, one can obtain a negative relationship, which is not true.

In this study, we proved that in the case of the Sverdlovsk region, the indicators of R\&D and ICT development costs are statistically significant: an increase in costs by $14 \%$ leads to an increase in the turnover in the SME sector by $27.3 \%$. In addition, in terms of the number of SMEs, the variable that reflects the share of the urban population turned out to be significant. An increase in the share of the urban population by $1 \%$ leads to an increase in the number of SMEs by 75.65 thousand units. Thus, the regional policy aimed at increasing these indicators will have a positive effect on the development of the small and medium-sized enterprises sector in the region.

The areas of further research are working out the tools to manage the development of small and medium-sized enterprises, as well as assessing the economic effect of the support measures on the main indicators of the socioeconomic development of the region.

\section{REFERENCES}

[1] S.V. Doroshenko, A.G. Shelomentsev, Econometric estimation of the number of young people as a part of the factors of development of small business in the region in: Economy of the region, 4 (2019) pp. 11151128. DOI: https://doi.org/10.17059/2019-4-12.

[2] Unified register of small and medium-sized businesses. https://rmsp.nalog.ru.

[3] ON. Knysh, E.V. Verlup, Target-programmed approach to the territorial development of small business in: Economy of the region, 12(2) (2016) pp. 427-437. DOI: https://doi.org/10.17059/2016-2-9.

[4] Passport of the national project "Small and Medium Enterprises and Support for Individual Entrepreneurial Initiatives" (approved by the Presidium of the Council under the President of the Russian Federation for Strategic Development and National Projects (minutes of December 24, 2018, No. 16)). http://static.government.ru/media/files/qH8voRLuh AVWSJhIS8XYbZBsAvcs8A5t.pdf.

[5] Small and Medium Business Sector: Russia and the World. http://stolypin.institute/wpcontent/uploads/2018/07/issledovanie-ier-msp27.07.18.pdf.

[6] N.Z. Solodilova, R.I. Malikov, K.E. Grishin, Regional system of entrepreneurship: parameters of development and potential for reconfiguration in: Economy of the region, 13(4) (2017) pp. 1107-1122.

[7] Strategy for the development of small and mediumsized businesses in the Sverdlovsk region for the period up to 2035. https://66msp.ru/images/515pp.pdf.

[8] G.V. Tikhonov, A.I. Tikhonov, Mathematical modeling in the system of innovative entrepreneurship in: Bulletin of SRSTU (NPI), 2 (2018) pp. 59-63.

[9] Office of the Federal State Statistics Service for the Sverdlovsk Region and the Kurgan Region. https://sverdl.gks.ru/folder/26395.

[10]Federal State Statistics Service. https://rosstat.gov.ru/statistic.

[11]Federal Law of July 24, 2007 No. 209-FZ (as amended on July 2, 2021) "On the development of small and medium-sized businesses in the Russian Federation." http://www.consultant.ru/document/cons_doc_LAW 52144/08b3ecbcdc9a360ad1dc314150a 632888670 3356.

[12] Kelly D. Edmiston, The Role of Small and Large Businesses in Economic Development in: SSRN 
Electronic Journal, 92(QII) (2007) pp. 73-97. DOI: https://doi.org/10.2139/ssrn.993821.

[13] T. Petkovska, The role and importance of innovation in business of small and medium enterprises in: Economic Development, 1(2) (2015) pp. 55-74. 